\title{
EVALUATION OF ANTIBACTERIAL EFFICACY OF DIGERA MURICATA \\ PLANT USING MICROBROTH DILUTION AND
}

\author{
AUTOBIOGRAPHY ASSAYS \\ ASHISH MALIK ${ }^{1}$, SUMAN LATA ${ }^{2} \&$ PREETI JAIN ${ }^{3}$ \\ ${ }^{I}$ Department of Botany, Maharshi Dayanand University, Rohtak, Haryana, India \\ ${ }^{2}$ Department of Chemistry, P.I.G Government College For Women, Jind, Haryana, India \\ ${ }^{3}$ Department of Biochemistry, Maharshi Dayanand University, Rohtak, Haryana. India
}

\begin{abstract}
INTRODUCTION

Bacterial infections treatment always remained as a challenge due to development of resistance in bacterial species.

OBJECTIVE

Medicinal plants contain a wide range of diverse molecules that provide a platform to search novel antibacterial agents.

MATERIAL \& METHODS

Digera Muricata plant material was sequentially extracted with five different solvents. Plant extracts were screened against gram +veand gram -ve bacteria for their antibacterial activity using micro-broth dilution and thin layer chromatography (TLC) based bioassay

RESULTS

Plant extracts of D. muricatas showed minimum inhibitory concentration (MIC) in a range of 0.156-5.0 $\mathrm{mg} / \mathrm{ml}$. A decreased MIC was observed along with the increased polarity of extraction solvents. TLC guided bio-assay of active plant extracts against different bacteria developed in different solvent systems. TLC of D. muricata chloroform extracts was developed in T:Ea:M::7:2:1 solvent system. Bio-autography of D. muricata chloroform extract showed two zones of bacterial inhibition.

\section{CONCLUSION}

Plant extract exhibiting significant MIC does not necessarily show the zone of bacterial inhibition in TLC based bioassays. Moreover, different extracts showed selective activity toward selective bacterial strains that can be used to identify the specific pathways in the bacteria or against specific types of infections.

KEYWORDS: Micro-Broth Dilution Assay, TLC, Bio-Autography, Anti-Bacterial Compounds \& MIC
\end{abstract}

Received: Feb 15, 2018; Accepted: Mar 05, 2018; Published: Mar 21, 2018; Paper Id.: IJBRAPR20182 


\section{INTRODUCTION}

Plants and herbs contribute to the medicinal system since the early age of humankind and are still being used throughout the world to treat pathogenic diseases and for health promotion. Plants are earliest and richest source of bioactive compounds even than bacteria or fungi were also not used to extracts antibiotics. The discovery of antibiotics greatly improved the quality of healthcare system and human life in the nineteenth century. Because of the initial success of antibiotics, bacterial diseases were considered to be permanently eradicated from human life. However, the clinical efficacy of these existing antibiotics is being threatened by the emergence of drug-resistant pathogens [1, 2]. It seems that pre-antibiotics era will return due to a failure of antibiotics in prevention and control of various diseases.

Plants still being a substantial source of bioactive compounds significantly contribute in the commercial drug preparation and form the basis of the modern medicinal system [3]. Plants contain secondary metabolites of a novel or known structures that lead to the production of semi-synthetic drug molecules of higher activity and lower toxicity. They are a reliable source to isolate bioactive compounds for direct use as drugs [4]. Plant- based drugs came into use through the screening study of medicinal plants because they showed few side effects, were cost effective and possessed better compatibility [5]. However, it is possible that recommending standardized herbal remedies with antibiotics for the treatment of infectious disease will prove a valid complementary approach in future if their safety and efficacy are clinically demonstrated. The aim of the present study is to evaluate the antimicrobial potential of DigeraMuricata, a local plant in Haryana, India used in Ayurveda and traditional medicinal system for treatment of various infections caused by pathogenic microorganisms. Further, TLC based bio-assay was used which is highly efficacious due to a target-directed isolation of the active compound even in a complex mixture of the crude extract[6, $7 \& 8]$.

\section{MATERIAL AND METHODS}

\section{Chemicals and Apparatus}

Hexane (hex), chloroform (chl), acetone (ace), methanol (met), dimethyl sulphoxide (DMSO) (Hi-media), HCl, ampicillin, nutrient broth, ethanol, resazurin dye, p-iodonitrotetrazolium violet (INT), autoclave (Hicon), laminar flow (Metrex), incubator shaker (Remi), Halo DB 20 spectrophotometer (Dynamics), sphinx vortex shaker (Tarsons), water bath (Hicon), centrifuge (Remi) and 96-well plates.

\section{Test Microorganisms}

Standard strains of the four gram-positive bacteria i.e. Staphylococcus aureus (NDCC-109), Streptococcus pyogenes (MTCC-1076), Bacillus cereus (NDCC-240) and Bacillus subtilis (NDCC-215) and four gram-negative bacteria, Klebsiella pneumonia(NDCC-138), Escherichia coli (NDCC-135), Pseudomonas aeruainosa ATCC-10145) and Salmonella typhi (NDCC-71)were used in the study.

\section{Collection of Plant Materials}

DigeraMuricata(Lesua) plant is traditionally well known for urinary tract disorder and other medicinal properties. Fresh and disease- free leaves plant was collected from their natural habitat Tiliyar, Rohtak, Haryana. Identification of the plant material was done through the Botany department of Maharishi Dayanand University, Rohtak and samples of plant materials were kept in the herbarium. Cross authentication of the selected plant was done with the help of flora of Haryana [9]. 


\section{Preparation of Plant Extracts}

Plant material was air dried by keeping in shade for 3 weeks. The properly dried plant material was crushed and grinded to fine powder. Afterward, $200 \mathrm{~g}$ of material was macerated three times for $72 \mathrm{~h}$ with five different solvents (100 $\mathrm{ml}$ each) in ascending order of polarity i.e. hex, chl, ace, met and water [10]. The combined extracts were filtered and solvents were evaporated to dryness in rota evaporator under reduced pressure below $45^{\circ} \mathrm{C}$ to yield a crude extract. Extracts were stored at $-20^{\circ} \mathrm{C}$ until further use. The percent yield of the crude extract in the different solvent was calculated by the following formula:

Percent yield $=\underline{\text { Weight of the crude extract obtained in gm }} \times 100$

Total weight of plant powder in gm

\section{Preparation of Inoculums}

A single colony of bacterial cultures from agar plate was transferred aseptically into flasks containing $100 \mathrm{ml}$ of nutrient broth and placed in an incubator at $35^{\circ} \mathrm{C}$. After $15-18 \mathrm{~h}$ of incubation, the cultures were centrifuged at $4,000 \mathrm{rpm}$ for $5 \mathrm{~min}$. The supernatants were discarded. The pellets were re-suspended in $20 \mathrm{ml}$ double distilled water and centrifuged again at 4,000 rpm for $5 \mathrm{~min}$. This step was repeated until the supernatant was clear. The optical densities of bacterial suspensions were measured spectrophotometrically at $600 \mathrm{~nm}$ and diluted serially until the optical density 0.6 achieved. This process was repeated for all the eight bacteria. The actual number of colony forming units was determined from the viability graph to calculate the required dilution factor. The cultures were diluted to obtain a concentration of $10^{6} \mathrm{cells} / \mathrm{ml}^{-1}$.

\section{Preparation of Test Material}

Plant extracts $10 \mathrm{mg} / \mathrm{ml}$ concentrations were prepared in DMSO or sterile water as stock solutions. The hex, chl and ace extracts of different plants were dissolved in 5\% (v/v) DMSO. Met extracts of different plants were dissolved in $2 \%(\mathrm{v} / \mathrm{v})$ DMSO. Aqueous $(\mathrm{aq})$ extracts were prepared in doubled distilled water. Ampicillin and streptomycin of 1.0 $\mathrm{mg} / \mathrm{ml}$ concentration were used in the study as the positive control.

\section{In-vitro Antimicrobial Susceptibility Assay}

The antibacterial activities of the extracts were determined by the micro broth dilution assay in 96-well plates[7]. Autoclaved $100 \mu \mathrm{l}$ nutrient broth was added to the wells of the culture plates. The first row of the microtiter plate was filled with $100 \mu \mathrm{l}$ of test material dissolved in DMSO or sterile water. Two- fold serial dilutions of extracts were done throughout the columns in the micro-well plates. Finally, $10 \mu 1$ of bacterial inoculum was added to each well. Proper positive and negative controls were kept for each experiment. Two columns one with streptomycin and second with ampicillin was taken as positive control. Plates were incubated at $35^{\circ} \mathrm{C}$ for $12 \mathrm{~h}$. After incubation, plated were removed from incubator and $10 \mu \mathrm{l}$ of resazurin dye $(4 \mathrm{mg} / \mathrm{ml})$ added to each well. Resazurin is violet-blue dye irreversibly reduced to the pink color in presence of a viable bacterial cell. The extracts were considered to be active if violet color appears in the well without any visible growth of bacteria. The results were expressed as minimum inhibitory concentration (MIC).

\section{Standardization of TLC Plate for Different Plant Extracts}

Different solvent systems were prepared by mixing defined ratio of different organic solvents and acids. Solvent 
systems were poured into the chambers and cover until saturation occurs. Plant extracts (chl, ace, met and aq extracts) were dissolved in enough organic solvent to have a concentrated solution instead of a turbid suspension. The $2 \mu 1$ of plant extracts $\left(5 \mathrm{mg} / \mathrm{ml}\right.$ ) was applied to TLC silica gel $60 \mathrm{~F}^{254}$ (Merck EMD Millipore, KGaA, Darmstadt, Germany) plates as narrow bands with a capillary, leaving a $0.5 \mathrm{~cm}$ border on the sides of the plates and developed in suitable solvent systems. TLC plates were dried overnight under the stream of air to remove residual solvent and mark the height of the solvent front \& position of bands with a pencil. TLC plates were visualized under visible and UV light and stored at $-20{ }^{\circ} \mathrm{C}$ till further use.

\section{Qualitative Antibacterial Activity Assay by Bio-Autography}

Bio-autography was done with agar overlay method. Inoculums were prepared by suspending the microorganism in nutrient agar media before it solidifies with an approximate concentration of $10^{6} \mathrm{cell} / \mathrm{ml}$. TLC plates were placed in sterile Petri-dishes and covered with $4.5 \mathrm{ml}$ of inoculum. Plates were kept at low temperature for some time until the media solidifies and incubated for $15-18 \mathrm{~h}$ at $35{ }^{\circ} \mathrm{C}$. After incubation, plates were sprayed with $2.0 \mathrm{mg} / \mathrm{ml}$ aq solution of piodonitrotetrazolium (INT) violet. Plates were incubated about $1 \mathrm{~h}$ at $36^{\circ} \mathrm{C}$. Clear zones on chromatograms indicate inhibition of growth and positions of active compounds in extracts [7].

\section{RESULTS}

\section{A yield of Plant Material}

Total five plant extracts were prepared from powdered materials ofD. Muricataplant. Different organic solvents were used in the increasing polarity order (hex, chl, ace, met and water) for the initial partitioning of plant metabolites. Overall, percent yield of plants extracts varied from 0.07 to $18.01 \%$. The percent yield of hexane extract of was negligible however highest in aqueous extract.

\section{In vitro Antibacterial Activity of Plant Extracts}

MIC of plant extracts obtained by microbroth dilution assay against different bacteria is summarized in Table 1 . MIC of ampicillin (positive control) varies in the range 0.0078 to $0.125 \mathrm{mg} / \mathrm{ml}$ against different bacterial strains. Plant extracts showed selective antibacterial potential against the different bacterial strain. Hexane extract showed the lowest MIC against gram+ve bacteria in comparison to gram -ve bacteria. Hex and chl extracts of D. muricata leaves were exhibited MIC in range of 0.098 to $2.5 \mathrm{mg} / \mathrm{ml}$ except for $E$. coli, whereas ace extract was moderately active and showed MIC in range of 0.625 to $5.0 \mathrm{mg} / \mathrm{ml}$. Aq extract didn't show reasonable activity. However, considerable better activities of this plant were observed against gram+veas compared to gram -ve bacteria. Extracts of this plant screened in this study were least active against $P$. aeruainosa and $E$. coli.

\section{Bio-Autography Assay}

TLC based bio-assay identifies the active band of antibacterial fractions from different plant extract. All five extract of this plant were screened against eight bacteria through bio-assay for identification of active band/compound. $R_{f}$ values of the active band, solvent system, susceptible bacteria and relative zone of inhibition are summarized in Table 2 . The inactive plant extracts were not included in bioautographic assays. Bio-autography of D. muricata chloroform extract showed two zones of bacterial inhibition DM1 and DM2 at Rf 0.12 and 0.44. DMI inhibits only B. subtilis whereas DM2 inhibits B. subtilis, B. cereus and S. aureus(Figure. 1). On the other hand gram -ve bacteria did not show any active band instead of having a moderate MIC. 


\section{DISCUSSIONS}

In most of the plant materials, it was observed that yield percent increases with increase in polarity of solvents. In all the plant's hex extract showed lowest and aq extracts showed highest yield percent. Plant extracts were found to be selectively active against bacterial spp. and activity decreased along with the increased polarity of extraction solvents. Moreover, plant extracts showed low MICs toward gram+ve then gram-ve. This difference was due to the ability of the compounds to penetrate inside the bacterium through the membrane. Gram+ve bacteria have a relatively loose outer wall and being hydrophobic nature of the membrane, compounds of less polarity can diffuse through it easier than polar compounds [11]. In other cases, gram-ve bacteria have a complex outer membrane that prevents the passage of many larger and non-polar compounds. Only a few compounds from the crude mixture of plant extracts can cross gram-ve membrane with a low rate of penetration. It explains the reason for higher MICs in gram-ve. Moreover, some compounds like standard drug penicillin G selectively act on a class of bacteria thereby it effectively kills gram+ve bacteria, but not gramve bacteria[12, 13].

MICs in case of D. muricata,were lower toward all gram+ve and gram-ve bacteria. This may be due to the common targets the bacteria. It was also observed plants extracts did not show any band against gram -ve and didn't show activity against E. coli and P. aeruginosa. These results indicated the specific and different targets in bacteria for these extracts/compounds to kill bacteria. Isoniazid, a popular drug to treat tuberculosis targets specifically to the mycobacteria, because it prevents the synthesis of mycolic acids, specifically found in the cell walls of mycobacteria and not in the most of other types of bacteria[14, 15]. In the present study, $25 \mu 1$ plant extract from a solution of $50 \mathrm{mg} / \mathrm{mL}$ was applied to the TLC plates. Hence, almost $12.5 \mu \mathrm{g}$ extract containing thousands of compounds was applied to the TLC plate. Therefore, the compounds exhibited either of broad range or of specific antibacterial activity toward selective bacterial strains and formed the clear zone of inhibitions in bio-autographic assays are of importance. Their activity was better or equivalent to the standard drug ampicillin. However, in some cases, crude extracts exhibited activity that was not observed in bioautographic assays. It indicated the synergistic action of some compounds present in the extracts. These active fractions DM1 and DM2 can be further purified by column chromatography and identified by MS/MS.

\section{ACKNOWLEDGEMENTS}

This research did not receive any specific grant from funding agencies in the public, commercial, or not-for-profit sectors. Authors are thankful to the Botany Department, Maharshi Dayanand University, Rohtak for identification and cross-authentification of plants used in this study.

\section{DECLARATION OF INTEREST}

Authors declare that they have no conflict of interest. All persons designated as authors are qualified for authorship.

\section{ETHICAL APPROVAL}

This article does not contain any studies with animals performed by any of the authors.

\section{REFERENCES}

1. Allen, H. K., Donato, J., Wang, H. H., Cloud-Hansen, K. A., Davies, J., Handelsman, J. (2010) Call of the wild: antibiotic resistance genes in natural environments. Nat Rev Microbiol, 8(4), 251-259. 
2. Bartoloni, A., Pallecchi, L., Rodríguez, H., Fernandez, C., Mantella, A., Bartalesi, F.(2009) Antibiotic resistance in a very remote Amazonas community. Int JAntimicrob Agents,33(2), 125-129.

3. Cowan, M. M. (1999) Plant products as antimicrobial agents. ClinMicrobiol Rev, 12(4), 564-582.

4. Balandrin, M. F., Kinghorn, A. D., Farnsworth, N. R. (1993) Plant-derived natural products in drug discovery and development: an overview. InACS symposium series (USA),1, 2-12.

5. Kinghorn, A. D., Balandrin, M. F. (1993) Human medicinal agents from plants. American Chemical Society, 1-6.

6. Sasidharan, S., Chen, Y., Saravanan, D., Sundram, K. M., Latha, L. Y. (2011) Extraction, isolation and characterization of bioactive compounds from plants extracts. Afr J Tradit Complement Altern Med, 8(1), 1-10.

7. Khond, M., Bhosale, J. D., Arif, T., Mandal, T. K., Padhi, M. M., Dabur, R. (2009) Screening of some selected medicinal plants extracts for in-vitro antimicrobial activity. Middle-East J Sci Res, 4(4), 271-278.

8. Masoko, P., Eloff, J. N. (2005) The diversity of antifungal compounds of six South African Terminalia species (Combretaceae) determined by bioautography. Afr J Biotechnol,4(12), 1425-1431.

9. Jain, S. P., Verma, D. M., Singh, S. C., Singh, J. S., Kumar, S. (2000) Flora of Haryana. Lucknow: Central Institute of Medicinal and Aromatic Plants, 6, 266.

10. Dabur, R., Gupta, A., Mandal, T. K., Singh, D. D., Bajpai, V., Gurav, A. M.(2007) Antimicrobial activity of some Indian medicinal plants. Afr J Tradit Complement Altern Med, 4(3), 313-318.

11. Silhavy, T. J., Kahne, D., Walker, S. (2010) The bacterial cell envelope. CSH PerspectBiol, 2(5), 414.

12. Warnke, P. H., Becker, S. T., Springer, I. N., Haerle, F., Ullmann, U., Russo, P. A.(2008) Penicillin compared with other advanced broad spectrum antibiotics regarding antibacterial activity against oral pathogens isolated from odontogenic abscesses. J CraniomaxillofacSurg, 36(8), 462-467.

13. Toku-E. Penicillin G. 2012.

14. Marrakchi, H., Lanéelle, G., Quémard, A.,Inh, A.(2000) A target of the antituberculous drug isoniazid, is involved in a mycobacterial fatty acid elongation system, FAS-IIMicrobiol, 146(2), 289-296.

15. Quemard, A., Sacchettini, J. C., Dessen, A., Vilcheze, C., Bittman, R., Jacobs, J. W. R., Blanchard, J. S. (1995) Enzymic characterization of the target for isoniazid in Mycobacterium tuberculosis. Biochem, 3(26), 8235-8241.

Table 1: MIC of Plant Extracts Against the Bacteria by Micro Broth Dilution Assay (mg/ml) in 96-Well Plates

\begin{tabular}{|l|c|c|c|c|c|c|c|c|}
\hline & $\begin{array}{c}\text { B. } \\
\text { Cereus } \\
(\mathbf{m g} / \mathbf{m l})\end{array}$ & $\begin{array}{c}\text { B. } \\
\text { Subtilis( } \\
\mathbf{m g} / \mathbf{m l})\end{array}$ & $\begin{array}{c}\text { S. } \\
\text { Aureus } \\
(\mathbf{m g} / \mathbf{m l})\end{array}$ & $\begin{array}{c}\text { S. } \\
\text { pyogens } \\
(\mathbf{m g} / \mathbf{m l})\end{array}$ & $\begin{array}{c}\text { E. coli } \\
(\mathbf{m g} / \mathbf{m l})\end{array}$ & $\begin{array}{c}\text { P. } \\
\text { Aeruainosa } \\
(\mathbf{m g} / \mathbf{m l})\end{array}$ & $\begin{array}{c}\text { S. } \\
\text { Typhi } \\
(\mathbf{m g} / \mathbf{m l})\end{array}$ & $\begin{array}{c}\text { K. } \\
\text { Pneumoni } \\
\text { ae(mg/ml) }\end{array}$ \\
\hline \multicolumn{7}{|c|}{ D. muricata } \\
\hline Hex & 0.156 & .098 & 0.098 & 0.625 & 2.5 & 0.625 & 1.25 & 1.25 \\
\hline Chl & 0.156 & .156 & 0.156 & 2.5 & 5.0 & 1.25 & 2.5 & 1.25 \\
\hline Ace & 0.156 & 0.156 & 0.625 & 2.5 & 5.0 & 1.25 & 2.5 & 1.25 \\
\hline Met & 2.5 & 0.156 & 5.0 & 5.0 & - & 5.0 & 2.5 & - \\
\hline
\end{tabular}

*Hex- Hexane, Chl- Chloroform, Ace- Acetone, Met- Methanol, Aq- Aqueous 
Table 2: TLC Guided bio-Assay of Active Plant Extracts Against Different Bacteria Developed in Different Solvent Systems

\begin{tabular}{|l|l|l|l|l|l|l|l|l|l|l|l|}
\hline \multicolumn{1}{c}{$\begin{array}{c}\text { Plant } \\
\text { Extract }\end{array}$} & $\begin{array}{l}\text { Solvent } \\
\text { System }\end{array}$ & Com & $\begin{array}{c}\text { Rf } \\
\text { value }\end{array}$ & BC & BS & SA & SP & EC & KP & PA & ST \\
\hline $\begin{array}{l}\text { D. } \begin{array}{l}\text { muricata } \\
\text { chl }\end{array} \\
\text { T:Ea:M: }\end{array}$ & $\begin{array}{l}\text { DM1 } \\
: 7: 2: 1\end{array}$ & 0.12 & - & ++ & - & - & - & - & - & - \\
\cline { 3 - 11 } & DM & 0.44 & ++ & +++ & ++ & - & - & - & - & - \\
\hline
\end{tabular}

Chl- Chloroform, T- Toluene, Ea- Ethyl acetate, M- Methanol, BC-Bacillus cereus, BS-Bacillus subtilis, SAStaphylococcus aureus,

SP-Streptococcus pyogenes, EC- Escherichia coli, KP- Klebsiella pneumonia, PA- Pseudomonas aeruainosa and ST- Salmonella typhi

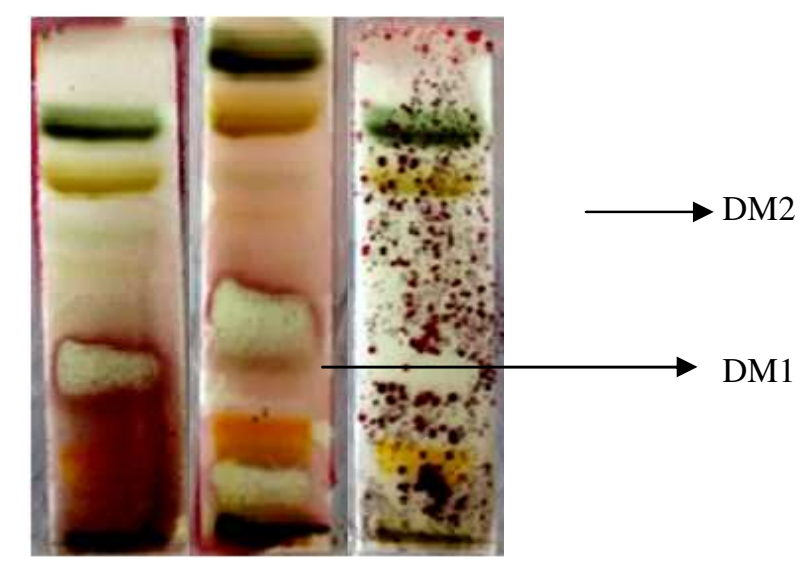

Figure 1: Bio-Autography of Different Plant Extract Against Pathogenic Bacteria Chloroform Extract of D. muricata(DM)Active Against

B. Cereus(C.1), B. Subtilis(C.2), and .S Aureus (C.3). 
